\title{
Trends and evolution of automobile ownership in the municipalities of Chile
}

\author{
Tendências e evolução da propriedade de automóveis nos \\ municípios do Chile
}

\author{
Francisco Maturana [a] (D), Mauricio Morales [b] (D), \\ Víctor Cobs-Muñoz [c] [D], Johana Maldonado [d] [D
}

\begin{abstract}
[a] Universidad Austral de Chile, Institute of Earth Sciences, Campus Isla Teja, Valdivia, Chile
[b] Universidad de Zaragoza, Department of Geography and Spatial Planning, Zaragoza, España

[c] TU Dortmund, School of Spatial Planning, Dortmund, Germany

[d] Universidad Alberto Hurtado, Geography Department, Santiago, Chile
\end{abstract}

How to cite: Maturana, F., Morales, M., Cobs-Muñoz, V., \& Maldonado, J. (2021). Trends and evolution of automobile ownership in the municipalities of Chile. urbe. Revista Brasileira de Gestão Urbana, v.13, e20210074.

https://doi.org/10.1590/2175-3369.013.e20210074

\section{Abstract}

The automobile has played a fundamental role in the development of cities in the daily movement of people. This paper analyzes the explosive increase in the number of motorized vehicles in the municipalities of Chile. Additionally, due to its national relevance, a disaggregated analysis of the Metropolitan Area of Santiago is presented. Through statistical data of the last 20 years, the analysis evidenced an explosive but differentiated increase of the automotive fleet. Results show the poorest municipalities with a lower dynamism, while those of the more affluent sectors experience exuberant increases. Particularly in the Metropolitan Area of Santiago, the results follow the same pattern, dynamics that jeopardize the planning and sustainability of national urban areas. A reflection is made focusing on the type of city that is being planned and built throughout the country and the urgency of a strategic public policy in urban public transport.

Keywords: Automobile. Transport. Spatial autocorrelation. Chile. Municipalities.

\section{Resumo}

O automóvel tem desempenhado um papel fundamental no desenvolvimento das cidades, no movimento diário das pessoas. Este artigo analisa o aumento explosivo do número de veículos motorizados nos municípios do Chile. Adicionalmente, devido à sua relevância nacional, é apresentada uma análise desagregada da Área Metropolitana de Santiago. Por meio de dados estatísticos dos últimos 20 anos, a análise evidenciou um aumento explosivo mas diferenciado da frota automotiva. Os resultados mostram os municípios mais pobres com menor dinamismo, enquanto os dos setores mais abastados experimentam aumentos exuberantes. Particularmente na

FM is associate professor, doctor in Territorial Planning, Urbanism and Space Dynamics, e-mail: francisco.maturana@uach.cl MM is collaborating professor, MSc. in Governance of Risk and Resources Qualification, e-mail: mtmorale@uc.cl VCM is research assistant, MSc. in Natural Resources Management \& Development, e-mail: victor.cobs@tu-dortmund.de JM is research assistant, graduate in Geography, e-mail: johanamaldonadof@gmail.com 
Área Metropolitana de Santiago, os resultados seguem o mesmo padrão, dinâmicas que comprometem o planejamento e a sustentabilidade das áreas urbanas nacionais. Uma reflexão é feita enfocando o tipo de cidade que está sendo planejada e construída em todo o país e a urgência de uma política pública estratégica no transporte público urbano.

Palavras-chave: Automóvel. Transporte. Autocorrelação espacial. Chile. Municípios.

\section{Introduction}

The development of cities throughout history has been linked to different purposes and dimensions, such as economic, social, environmental, transportation, among others. The latter has played an important role in the growth of countries as an essential element for the lives of people living in urban areas. For Elmansouri et al. (2020), the growing demand for transport services in cities is the result of urbanization, population growth, rising living standards, and the development of business and industry.

From a perspective of sustainable cities, the development of the means of transportation finds its origin in the 80s decade, where the focus was to lowering the externalities produced by the use of automobiles. The strategic planning of land use and transportation became one of the main elements for urban sustainability (Johansson et al., 2017), where the role of planners has been to equilibrate negative with positive aspects arising from this, being contamination, traffic congestion, and excessive traffic, with increasing accessibility to urban goods and services and reducing the difficulties of people moving within a city (Curtis, 2008), respectively.

In urban areas, travel times in terms of traveled distances between locations have changed significantly as a result of the emergence of mechanical means of transport for the movement of people. If in the 19th century the roads allowed horses or stagecoaches to travel at speeds of up to $10 \mathrm{~km} / \mathrm{h}$, today the number of journeys has increased at least eightfold (Pumain, Bregtanolle \& Degorge-Lavagne, 1999). The increase of journeys would not have been possible without the evolution of physical support, in which a fundamental role has been played by land communication routes (particularly highways), which are transformed into true arteries that channel the relations between the nuclei and the economic activities they allow to be carried out (Coronado \& Garmendia, 2008). These roads have made notable progress in their physical development, in terms of widening and paving the infrastructure (Echeñique, 1995).

There is a, a reconfiguration of the morphology of cities, questioning their sustainability and translating into debates and responses around the mobility that inhabitants develop within or between them (Camagni, Gibelli, \& Rigamonti, 2002). Particular effects can be observed in the amount of land-use change and land destined for roads, parking spaces, and maintenance (Dávalos, Maldonado \& Polit, 2016), and how these elements acted as structural elements of the construction of the city that has been planned and executed in the past and projected for the future, at least in the national context of Chile and Latin America.

The contribution of this work lies in first giving a general panorama of the situation in the different municipalities of Chile and then, due to its national relevance, focusing the analysis on the Metropolitan Area of Santiago. In particular, results lean towards municipalities with high levels of access to automobiles are those with historically lower levels of poverty, higher incomes, and higher quality of life, despite this high rate of motorization. Therefore, the focus is set on the development of three objectives. The first one corresponds to correlating the number of automobiles with the population of Chile's municipalities during the periods of 2002, 2012, and 2017.

The second one consists of analyzing particular behaviors of the municipalities' population in the automobile market, exploring relationships in terms of poverty, wealth, and quality of life. Next to this procedure, it is possible to understand the inequities in the distribution of the motor vehicle fleet in the capital of the country, contained in the Metropolitan Area of Santiago. This urban area concentrates $40 \%$ of the country's population (INE, 2017), being this the reason why it is appropriate to conduct a particular analysis for this specific area. 
Finally, it is proposed that, according to the dense data presented for the national level and the Metropolitan Area of Santiago, it is urgent to make these elements visible, whose diagnosis will make it possible to have more alternatives in the elaboration of public policies, which should be set within the framework of the New National Policy of Urban Development elaborated in 2014, which is currently in process for its application by the national administration.

\section{The role of the automobile in the development of cities}

Transport is considered an important element in the development of a country and a city in terms of economic, social, and political stability, where the use of the automobile is widespread in some urban areas and affecting dimensions of security, income, and quality of life (Barbero \& Galeota, 2019; Sheller \& Urry, 2008). In this sense, Coronado \& Garmendia (2008) state that there is a change in the paradigm of the use of transport within cities and that it was born after World War I. This event encouraged the development of the automotive industry to expand its use in transporting passengers and goods, initially complementing the railway, but gradually becoming a powerful competitor of this and other means of mass transport. In fact, it will not be until the intensification of the development of the process of globalization and economic liberalization, supported by the Asian market in vehicle production, where financialization was linked to segmented consumption and global areas in terms of demand satisfaction (Basurto, 2010).

However, not all cities would behave similarly since the rates of automotive fleet growth are differentiated, therefore, their associated impacts are differentiated as well. This communication addresses the hypothesis of a high correlation between the amount of population and the motor vehicle fleet, observing cases that escape this rule reflecting the strong contrasts associated with the wealth of the municipalities under study. Although it is known that there is such a correlation, in countries like the United States, access to automobiles is common and the difference lies in the quality rather than access. On the other side, for European areas, it is often an option, given the strengths of public transport. In both cases, there are global and local factors that affect these differences, such as processes of economic development of nations, increases in the quality of life linked to the mobility of individuals, and increases in household incomes (Muhammad et al., 2012).

\section{Effects/impacts of automobile for urban planning in Latin America}

In the context of Latin American metropolises, the automobile has a fundamental role in the displacements at a local and regional scale (Hidalgo \& Huizengra, 2013). These dynamics favor the extension, consolidation, and therefore production of a diffuse and dispersed city. It is possible to highlight, as an example of these dynamics, the metropolises of Santiago, Buenos Aires, Rio de Janeiro, and Panama (Figueroa, 2005; Pérez \& Salinas, 2007). Thus, the automobile emerges at the beginning of the twentieth century, mainly imported from Europe and the United States, where countries like Argentina, Uruguay, Cuba, Panama, and to a lesser extent, Chile (Errázuriz, 2010) managed to be the main actors in such market, linked primarily to the wealth experienced by these States (Yáñez y Badia-Miró, 2011).

Evidence shows that while the distances traveled in the interior of cities have increased, problems have arisen correspondingly within these cities, particularly when movements are not carried out in an efficient and comfortable way, as occurs in Latin American countries (Machao da Silva, et al., 2019). In its early years, the automobile was more accessible to wealthy classes, and its use was oriented towards recreational and tourist travel (Errázuriz, 2016). In this process, the rate of motorization increases, massifying automobile ownership, and therefore, morphologically modifying Latin American cities (Figueroa, 2005). In addition to this, the region sustained greater access to credit and income for households, transforming the acquisition of an automobile into a symbol of a new society, generating distinctive social practices and categories, such as social status, aesthetics, or power (Ureta, 2009). 
Nevertheless, in Latin America the situation is different, and particularly Chile is facing a specific case where access would be more, taking into account the purchasing power of people living in the cities and whose impact, despite such an increase, would not affect the quality of life in such areas. Specifically, the idea of the quality of life in matters of urban transport analysis, stated in specialized literature, is based on the dependence on the use of the automobile (Tiwari, 1999). This use generates effects in matters of pollution and environmental degradation, traffic congestion, vehicular accidents, and/or deterioration of public space, among others (Barter, 2001). Therefore, in terms of quality of life, the negative effects generated by the use of the automobile, impact directly and indirectly those people in cities who do not make use of an automobile, affecting the urban space as well.

\section{Consequences of the automotive boom in urban areas: The Chilean case}

In Chile, the historical use of the automobile can be linked to the higher income sectors that continue to be located in peripheral areas of the city, assuming the mobility costs anchored in the automobile and disconnected from public transport (Lukas \& Morales, 2018), a dynamic that extends to these days. At the same time, the less well-off sectors, often also located in peripheral areas, are forced to use public transport that is often inefficient and insecure. This reality opens up an important debate on the social justice of mobility and transport, sustained by new demand logics, linked to cyclists and pedestrians (Tiznado-Aitken, Muñoz, \& Hurtubia, 2018). In this sense, public transport policies have not been able to successfully incorporate the contributions of the inhabitants in terms of improvements in accessibility (Sagaris, 2018). This social failure is mainly due to strong pressure from the private sector, whose influence has been present in the last 40 years, thus determining the transportation policies experienced by various cities in the national territory (Figueroa, 2013).

The automobile in Chile advances in a vertiginous way. According to Chile's National Institute of Statistics (INE; acronym in Spanish for Instituto Nacional de Estadísticas), the national vehicle fleet has quadrupled in 18 years. If in 2000 there were 1,314,129 motor vehicles (INE, 2001), by the end of 2018 this number rises to 5,382,604 (INE, 2019), highlighting the Metropolitan Region of Santiago (2,124,481 units), the Region of Valparaíso $(570,922)$, and the Region of Biobío $(434,336)$ (INE, 2019).

Therefore, in the face of the effects generated by the automobile boom in Chilean cities, urbanization processes around transportation have enabled the existence of spatial fragmentation processes in the structure of connection networks, and the disconnection between strategies at regional and local scales (Hernández \& Dávila, 2016).

\section{Data collection}

Since the analysis unit corresponds to Chilean municipalities, these entities had to be delimited in order to collect, prepare, and associate a database from the information of the national vehicle fleet between 2000 and 2018, which was extracted from different "Automotive Fleet Yearbook" provided by the INE. In the same way, and from the same governmental institution, population data were extracted from the censuses of 2002, 2012, and 2017. Regarding the mentioned Automotive Fleet Yearbook, it is necessary to clarify some elements in their preparation that must be considered when interpreting the data.

The collection of information is made according to the municipality where each automobile is registered and the circulation permit fees are subsequently paid annually. It is not mandatory for the owners of an automobile to register it in their municipality of residence. However, there is a high incentive to do so considering that the collected income from automobile circulation permits (which are paid where it is registered) is one of the largest freely available economic sources of income of each municipality nationwide. Therefore, every municipality tries to capture as many circulation permits as possible. Each year they carry out advertising campaigns encouraging their inhabitants to do so in their municipality, with general promises to recirculate the funds into investment in green areas, security, street improvement, etc. 
Another aspect to highlight is that the values of these permits are nationally set and they are equal for every municipality. Therefore, there is no incentive in attracting automobile registrations to a specific municipality. Besides, there are currently common virtual platforms for the different municipalities in terms of automobile registration, which does not present a greater bureaucratic differentiation either.

Regarding the census base for 2012, it should be noted that, although the census of 2012 has an unofficial character, it made it possible to have the population quantity per municipality on that date. The databases are characterized in a general way to understand the distribution and behavior of these (see Figure 2).

\section{Methods}

To analyze the dynamics of the automotive fleet for the Chilean city system a two phases quantitative method was used (see figure 1).

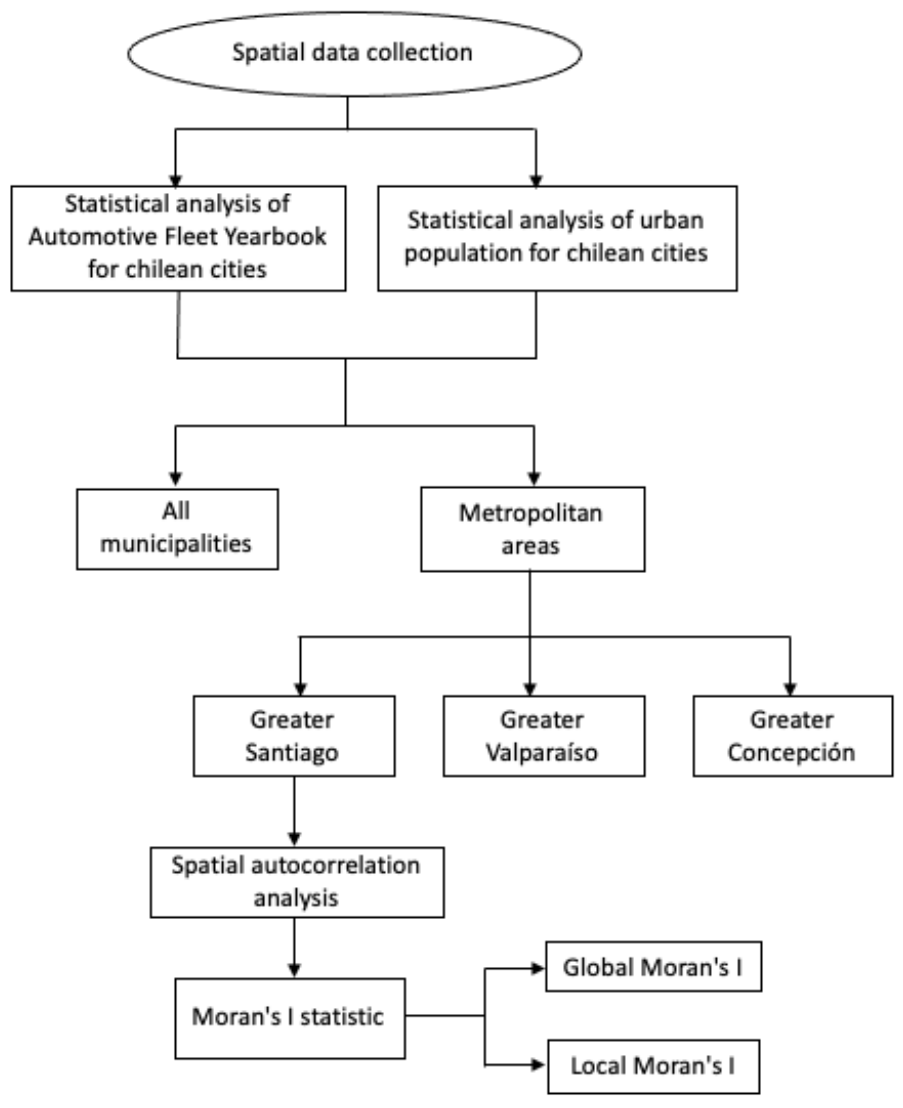

Figure 1 - Method summary. Source: Authors.

\section{Simple linear regression model}

Once the database 'Automotive Fleet Yearbook' was compiled, a linear regression model was performed following its equation $(Y=\beta 0+\beta 1 X+\varepsilon)$. Being $\beta 0$ the ordered one in the origin, and $\beta 1$ the slope, where the variables used were the communal population (independent variable) and the motor vehicle fleet (dependent variable). This process was carried out for each analyzed period and two databases. The first one comprised all the municipalities and the second one without the three biggest metropolitan areas of the country, that is 'Greater Valparaíso', 'Greater Santiago', and 'Greater Concepción'. The objective was to examine the behavior of the model without the influence of these three conglomerates. Once the regression was done, the corresponding residual values were analyzed. All the previous procedures were carried out 
using R environment and the results are presented in graphs. In a complementary way, the evolution of the automotive fleet is expressed for regional and provincial capitals.

\section{Spatial autocorrelation analysis}

The next step was to deepen the specific analysis for Greater Santiago or AMS, the capital of the country. This urban agglomeration concentrates approximately $37 \%$ of the total national population (INE, 2017). The objective was to determine the disparities within the area, which contains 32 municipalities.

For this purpose, Global Moran's I (Moran, 1948) and its local application (Local Moran's I) were used as forms of determining spatial autocorrelation and relationships between different spatial units (Anselin, 1995). GeoDa software was used to obtain global and local spatial autocorrelation values for the set of municipalities that compose the AMS. It was performed univariate analyses for the variable "number of automobiles per inhabitant", which corresponds to the motorization rate, for the periods 2002, 2012, and 2017. The Global Moran's I statistically explain to what extent the spatial variables are grouped (positive autocorrelation), dispersed (negative autocorrelation), or randomly distributed. Global Moran's I take values ranging from -1 (maximum negative autocorrelation) to 1 (maximum positive autocorrelation), where 0 indicates no possibility of spatial autocorrelation (Gutierrez and Delclòs, 2016). Global Moran's I is defined by Anselin (1995) as shown in equation 1.

$$
I=\frac{\sum_{i=1}^{n} \sum_{j=1}^{n} w_{i j}\left(x_{i}-\bar{x}\right)\left(x_{j}-\bar{x}\right)}{\left(\sum_{i=1}^{n} \sum_{j=1}^{n} w_{i j}\right) \sum_{i=1}^{n}\left(x_{i}-\bar{x}\right)^{2}}
$$

Where I correspond to Moran's I statistic, $x_{i}$ is the value of the variable for location $i, x_{j}$ is the value of the variable for location $j$, and $w_{i j}$ as the elements of the spatial weight matrix where the inverse distance between the elements of the matrix between $i$ and $j$ is assumed, and $n$ as the number of total observations.

Likewise, when obtaining the values of the autocorrelation indicator at a global level, we proceed to use the local version of this indicator $\left(I_{i}\right)$ that corresponds to the Local Moran's I (Anselin, 1995) that allows deepening the clustering analysis at a spatial level. This indicator at the local level is defined in equations 2 and 3 as:

$$
I_{i}=\frac{x_{i}-\bar{x}}{S_{i}^{2}} \sum_{j=1, j \neq i}^{n} w_{i, j}\left(x_{j}-\bar{x}\right)
$$

Where,

$$
S_{i}^{2}=\frac{\sum_{j=1, j \neq 1}^{n}\left(x_{j}-\bar{x}\right)^{2}}{n-1}
$$

With $n$ as the total number of observations.

For the spatial representation of clustering analysis and outlier determination (Local Moran's I), maps of Local Indicators of Spatial Association (LISA) were used. In particular to identify areas with high and low values (p-value $<0.05$ ), and those outliers that do not represent clustering at a $95 \%$ confidence level (Anselin, 2005).

\section{Components of the urban transport problem}

Lastly, for the case of the AMS, the analysis is complemented with four regressions, which seek to explore relationships of the number of automobiles per inhabitant with variables of poverty levels, average household income, quality of life, and the average length of streets. For the first two variables, the 
information is extracted from the National Socioeconomic Characterization Survey (CASEN; acronym in Spanish for Encuesta de Caracterización Socioeconómica) for the year 2017. For the quality of life variable, the index prepared by the Chilean Chamber of Construction is used, together with the Pontificia Universidad Católica de Chile. This index has been developed continuously from 2011 to date, being a reference and used in various works (Orellana et al., 2013). For this particular work, the values obtained in 2017 are used. Finally, the variable average length of streets, avenues, highways, and road networks of lower hierarchy are based on the master cadaster of streets provided by the INE (2018b)

\section{Study area}

Chile is constituted by 16 regions in which are located 346 communes and 345 municipalities (see Figure 2). In fact, in each commune there is a municipality, and practically in all communes exists one city inside of them (Morales, 2015), understood as an urban entity with over 5,000 inhabitants according to the INE (2019). Thus, for this study, it was selected municipalities whose population surpasses 10,000 inhabitants, in such a way to consider mostly urban spaces. Additionally, according to the guidelines of the National Institute of Statistics of Chile (INE) declared spaces were conurbated (2018a, 2019). In Figure 2, it is possible to appreciate the location and population of the municipalities over 50,000 inhabitants since a lower threshold did not facilitate their understanding.

\section{Results}

The descriptive analysis of the population variables for the 175 municipalities of study allows us to infer that there is no major change in the distribution of the urban population between 2002 and 2017, that is, the hierarchy. These elements are not surprising given the regular behavior in such distribution when observing urban systems (Pumain, 1997). Thus, Greater Santiago, Greater Valparaíso, and Greater Concepción are at the top of the urban hierarchy (Figure 3), situation has not changed in the last 20 years.

However, regarding the 'behavior' of the automobiles for each of the periods 2002, 2012, and 2017, Figure 3 shows how this distribution has changed substantially, showing an increase in its maximum and minimum values, as well as its average values. Concerning the minimum, in 2002 there were 221 automobiles, and by 2017 this number will increase sixfold, that is to 1,459 automobiles. As for the average, the variations are also quite explicit. For the 2002 period, the average number of automobiles per municipality was 11,821, in 2012 it rises to 21,041 and in 2017 it rises to 27,280 automobiles on average, practically tripling in this last period. However, the standard deviation has also increased considerably, which is an indication that the distribution in the municipalities of such increase has not been equal. If in 2002 the standard deviation was $66,007.6$, it increased to $141,753.4$. 


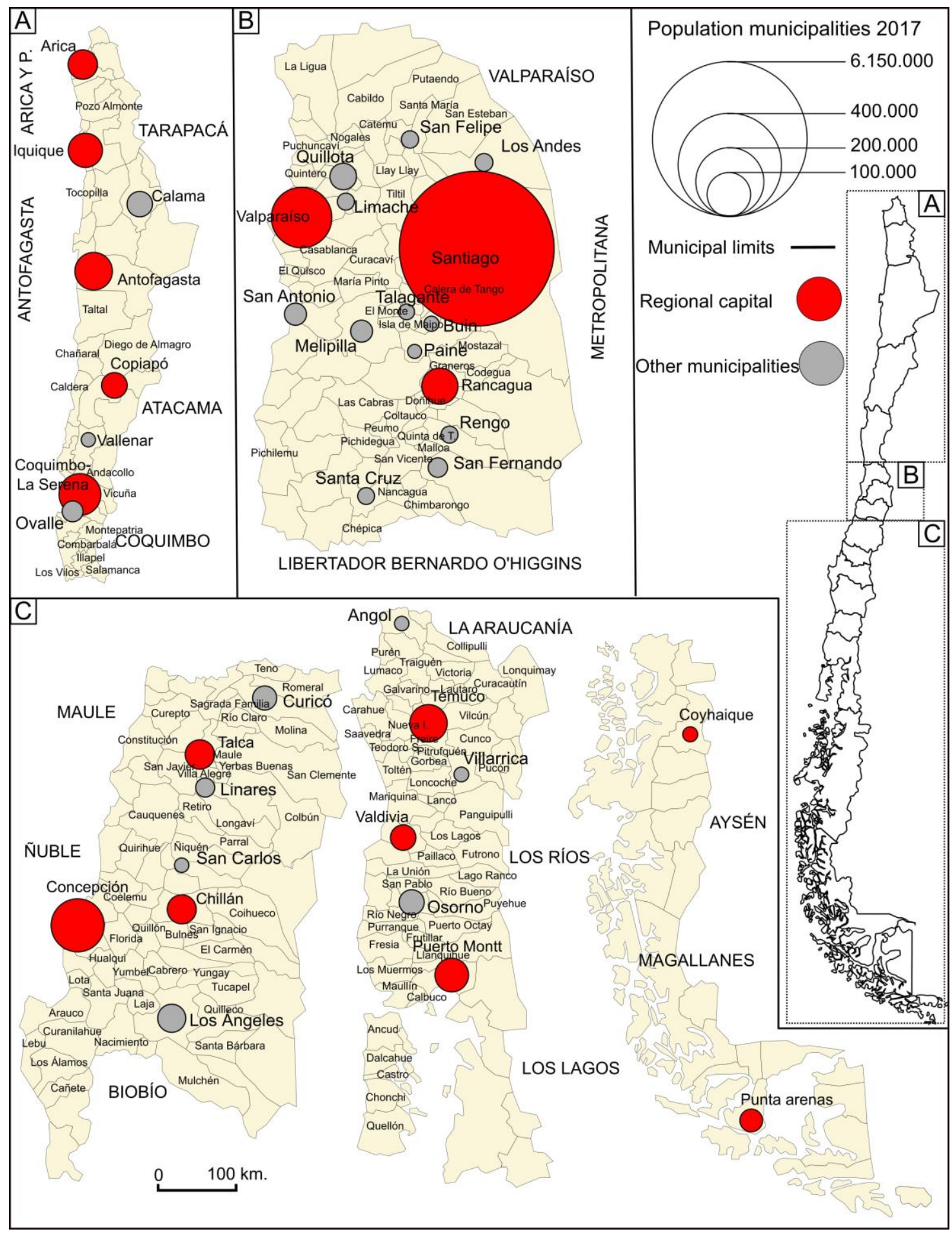

Figure 2 - Municipalities with population over 50.000 inhabitants, census 2017. Source: Authors' elaboration based on INE (2017). 

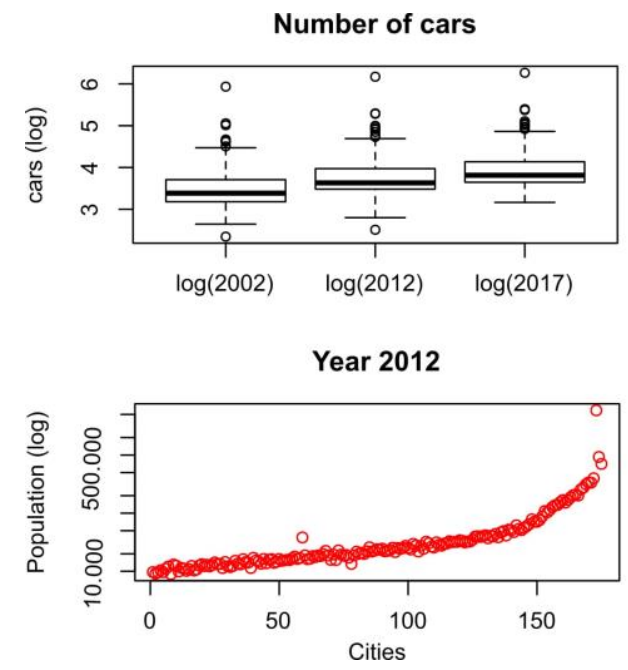

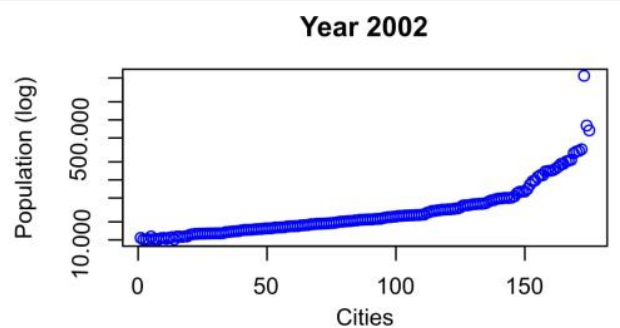

Year 2017

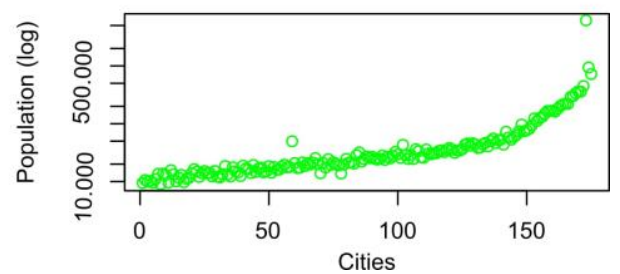

Figure 3 - Characterization of data distribution according to the databases built for the communal population and the automotive fleet. Source: Authors' elaboration based on the automotive fleet yearbooks and INE 2002, 2012 , and 2017.

\section{Analysis of the vehicle fleet within the city system}

In Figure 4, it is possible to see that there is a strong correlation between population variables and motor vehicles, as is the case elsewhere in the world (Cottineau et al., 2017; Ramanathan, 2000), where R2 varies between 0.999 and 0.893 for all years and databases used.

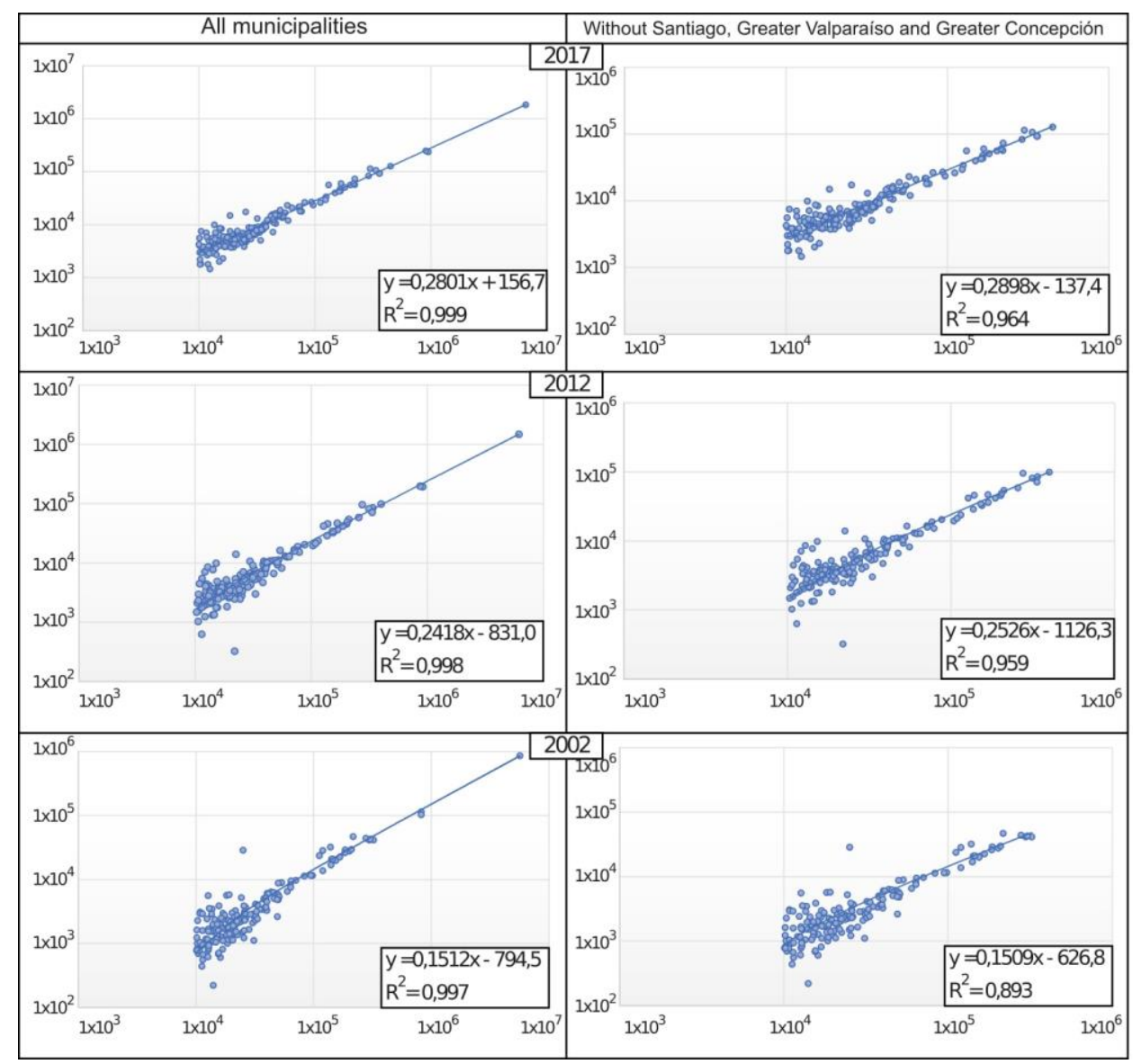

Figure 4 - Simple linear regression model Source: Authors' elaboration based on the automotive fleet yearbooks and INE 2002, 2012, and 2017 (axes x population and y motor vehicles).

Analyzing the graphs on the left side of Figure 4, it is possible to observe the regression including the three metropolitan areas (Greater Santiago, Greater Valparaíso, and Greater Concepción). As shown in the 
x-axis, Greater Santiago has a population considerably higher than the rest of the municipalities of the national system, bordering the 6 million inhabitants. However, by suppressing the three metropolitan areas and observing the regressions on the right side of said figure, the three graphs do not show significant changes in its R2 (coefficient of determination), rather the observed trend is maintained.

In 2002, five municipalities in the La Araucanía Region emerged among those with fewer vehicles related to their population, the same is true for the periods 2012 to 2017, where this ratio increased to six municipalities. It should be noted that this Region had the highest poverty rate in the country in 2017, practically 8 percentage points above the national average (multidimensional poverty). Thus some municipalities that emerge with negative residuals like Lonquimay (Andean municipality), presented 54.9\%, Galvarino 54.4\%, Freire 34.1\%, Calbuco 41\%, or Nogales 39.1\% (Casen, 2017). Another case linked to poverty levels and particularly high unemployment is the municipality of Lota in the Biobío Region, whose levels were around $20 \%$ in 2017.

Another municipality that interestingly emerges from this analysis is the case of Calera de Tango, which can be seen in the three periods analyzed. This municipality is located in the southern area of the Metropolitan Region of Santiago and has presented in recent years an important dynamism in terms of real estate, where more affluent sectors have sought a residence of greater size and experience of the 'rural' without being disconnected from the urban context (Cox \& Hurtubia, 2016), in line with the hypothesis raised in the introduction of this paper.

Regarding the general behavior of the obtained residual values, which can be seen in Figure 5, it can be observed that the cloud of points behaves in an inverted manner, reflecting an increase in the variance as the value of the independent variable decreases (amount of population). The result that could be interpreted from the previous fact is that in the municipalities of Chile, a greater number of vehicles in proportion to the population is contemplated.

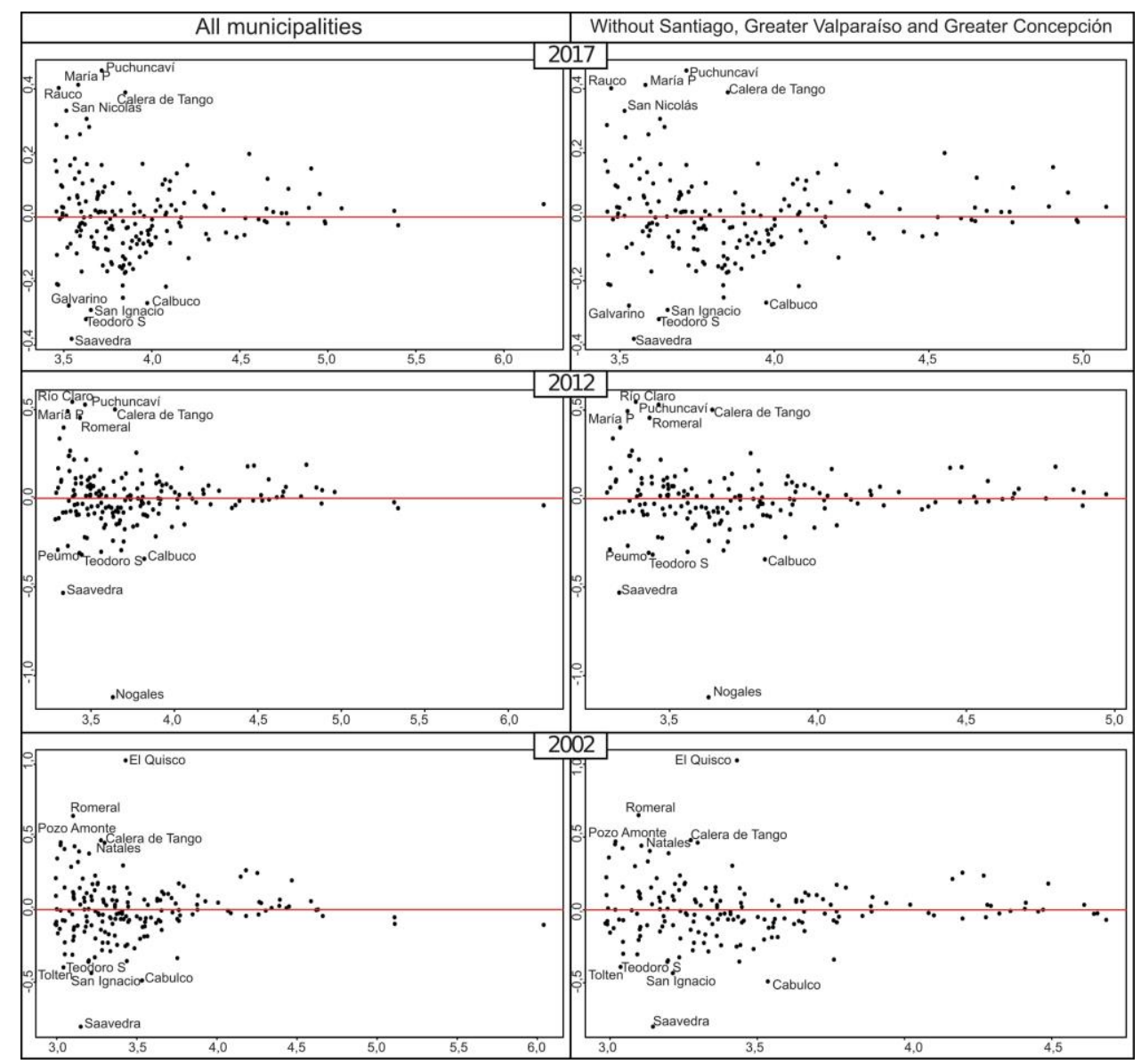

Figure 5 - Residual values for each database. Source: Authors' elaboration based on the automotive fleet yearbooks and INE 2002, 2012, and 2017. 
In order to observe in detail, the residual values, Figure 6 was prepared. Said figure expresses the first 10 municipalities that present the highest residual values and the 10 territories with the most negative residual values for each year in question.

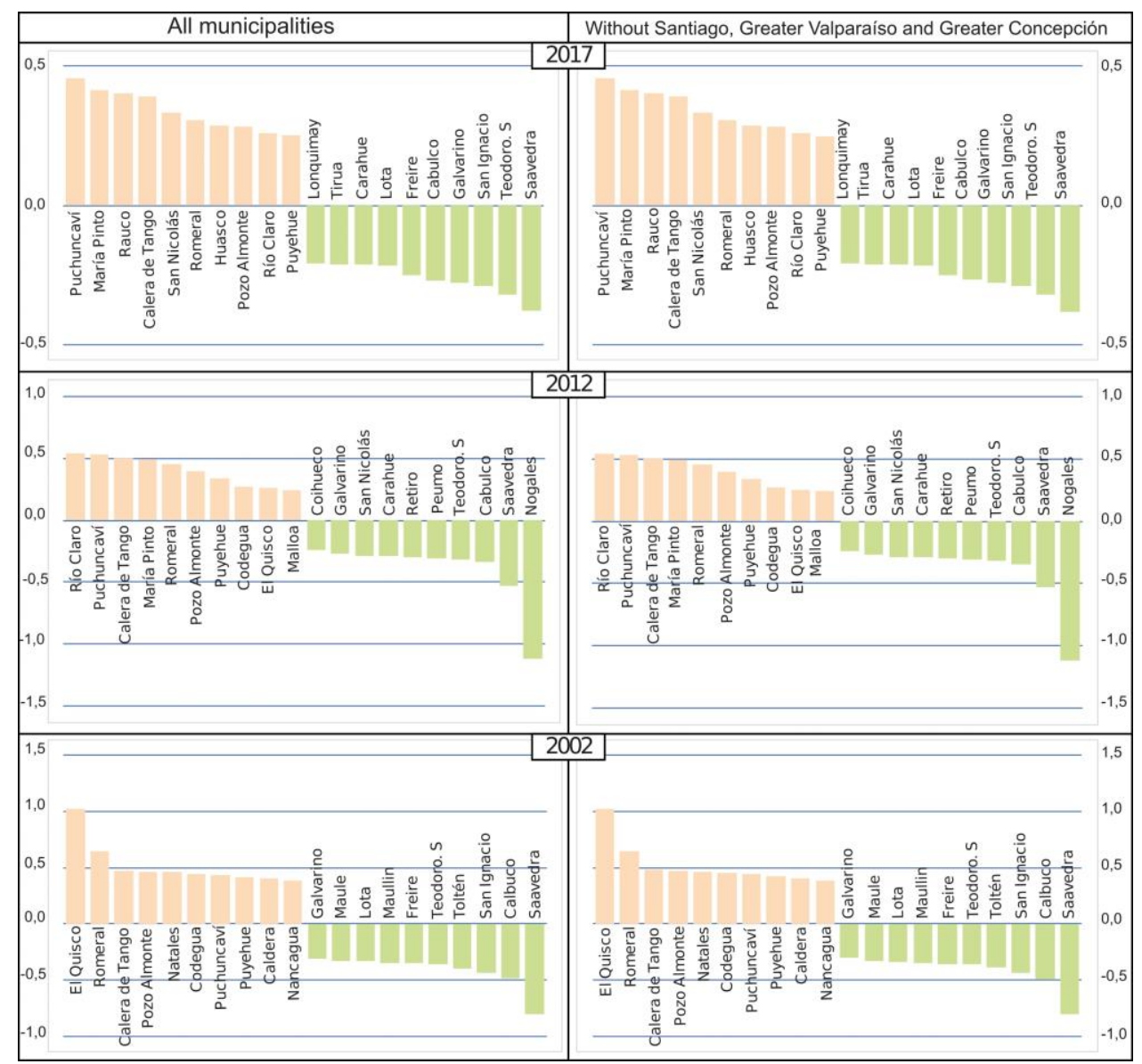

Figure 6 - Municipalities with high residuals and negative values. Source: Authors' elaboration based on the automotive fleet yearbooks and INE 2002, 2012, and 2017.

As can be seen in Figure 6, there is a repetitive pattern over the years of the municipalities in terms of residuals, for example, in the positive ones, El Quisco, Romeral, or Puchuncaví. In the case of the negative ones, the high presence of municipalities belonging to the La Araucanía Region in all periods was already indicated. The poorest municipalities generally have less access to automobiles than the richest ones. In addition to the trends already observed, the aim was to analyze what was happening particularly in the country's regional and provincial capitals. For better visualization of the trends, Figure 7 was elaborated, consisting of 4 subdivisions. These show the evolution of the motor vehicle fleet from 2001 to 2018 .

At the top of Figure 7, the graph of the 'regional capitals' municipalities excludes the three classic metropolitan areas of the country to have a better visualization. The first element that can be pointed out in the said graph is that, although some municipalities have been faster than others, practically all doubled their automotive fleet in 10 years if the period between 2008 and 2018 is considered. In this sense, the first four municipalities that stand out are Coyhaique (2.1), Arica (2.0), Coquimbo-La Serena conurbation (2.0), Rancagua-Machalí conurbation (2.0), and Puerto Montt-Puerto Varas conurbation (1.9). The last three are linked to primary activities and have had a strong dynamic in recent years, both in mining and salmon farming, that is, territories where income has increased. 


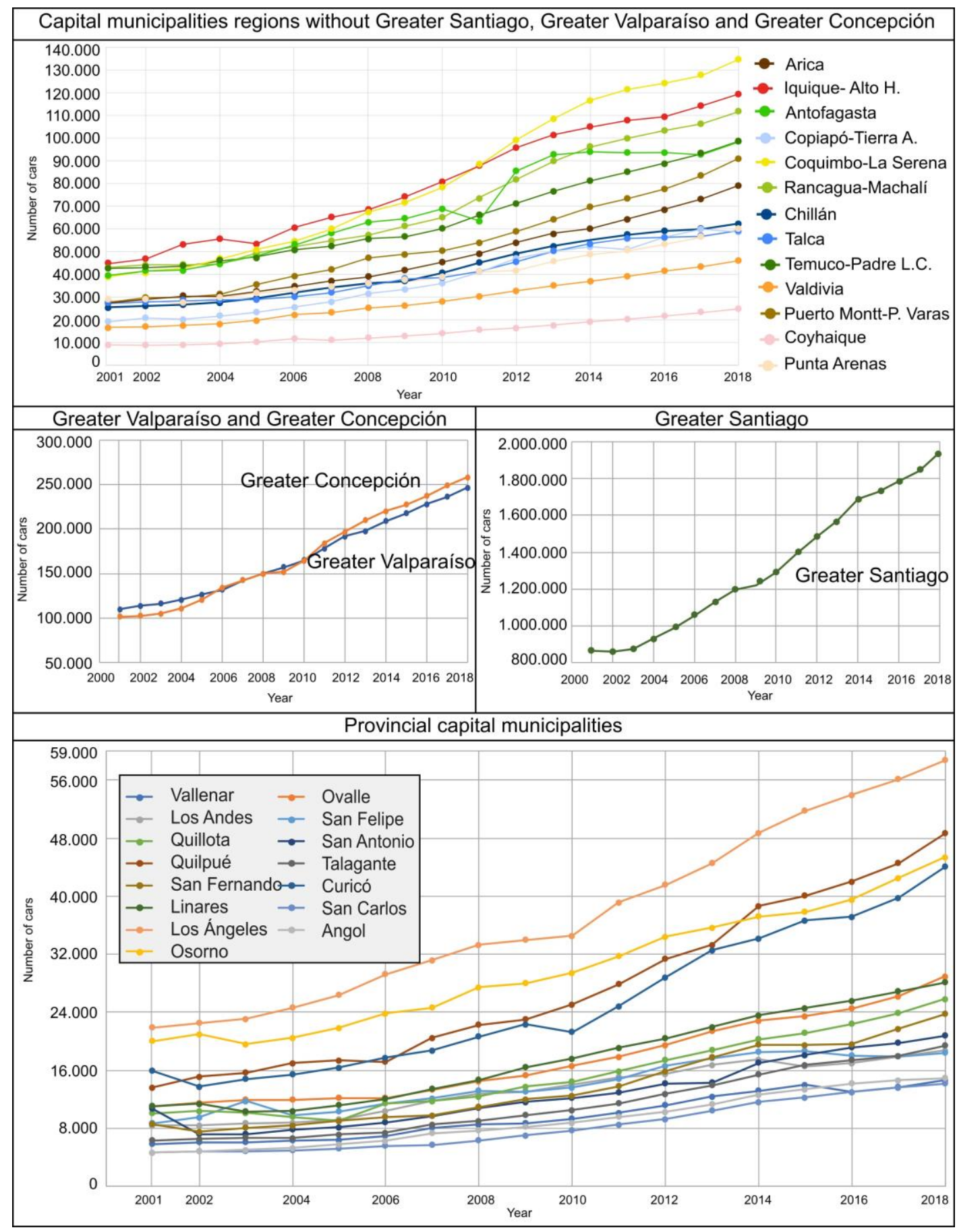

Figure 7 - Evolution of the motor vehicle fleet in the country's main municipalities that hold the rank of a regional or provincial capital in the political-administrative division. Source: Authors' elaboration.

If the context of the 17 years of study is considered, the situation changes. Some municipalities have tripled the number of motorized vehicles, while others have only doubled it. Among the 5 most dynamic ones are the conurbation of Coquimbo-La Serena (3.5), Puerto Montt-Puerto Varas (3.3), Copiapó-Tierra Amarilla (3.1), Arica (2.9), and Coyhaique (2.8). The first three stand out for territories whose income and links to primary productive activities are extremely relevant.

On the other hand, as far as the metropolitan areas are concerned, it is evident that the municipalities that compose the Greater Concepción have presented a larger dynamism than the Greater Valparaíso. This is due more to the morphology of the city and transport policies. The first great area presents the train (named Biotren) that remains incipient, giving prominence to the automobile. Besides, its urban development has been extended by the coastal sector. On the other hand, the area of the Greater Valparaíso is also covered by a single-route train (named Metrotren) and its expansion has tended to develop inland 
since several coastal communities emerge somewhat 'confined' by different landforms.In the case of the Greater Santiago, it has shown an upward curve, with a slight stabilization between 2008 and 2009, observable in the other two conglomerates and where the world economic crisis is expressed. The comparison of these 3 areas is necessary to be made in relative terms.

In 10 years, Valparaíso and Santiago present 1.6 times more automobiles, while the case of Concepción is 1.7. In the 17 years analyzed, Greater Valparaíso doubles its vehicle fleet (2.2 times), Greater Concepción 2.5, and Greater Santiago 2.3. If we contrast these results with the previous ones, we observe that without a doubt the regional capitals have been much more dynamic relatively than the metropolitan areas.

In the same figure, the graph of the 'provincial capital' municipalities, highlights Quilpué that tripled its vehicle fleet (3.5), Angol (3.2), Talagante (3.1), and San Carlos (3.0). In the case of the first one, it is directly linked to a metropolitan area such as Valparaíso. Talagante, located in the Metropolitan Region of Santiago and its proximity to the city of Santiago. The case of San Carlos, located in the Nuble Region, whose proximity to Chillán could be one of the reasons for the high rate of commutation.

\section{Cluster analysis of the automotive fleet: the case of Greater Santiago or AMS}

Greater Santiago is the main metropolis of Chile, which in the last 20 years has experienced deep morphological changes, oriented rather to a diffuse space, with high commutations. Thus, from the perspective of geostatistics, it is observed that when applying a spatial autocorrelation analysis for the indicator 'Quantity of Automobiles per Inhabitants' for the municipalities of the Greater Santiago there is a clear tendency towards the spatial grouping of municipalities for the periods 2002, 2012, and 2017 (see Figure 8). Consequently, the existence of association through the Global Moran's I method evidences that there exist groups of municipalities that reunite the same conditions of self-value, this is, that their amounts of automobiles per inhabitant are similar, being those statistically significant ( $p$-value $<0.05$ ).
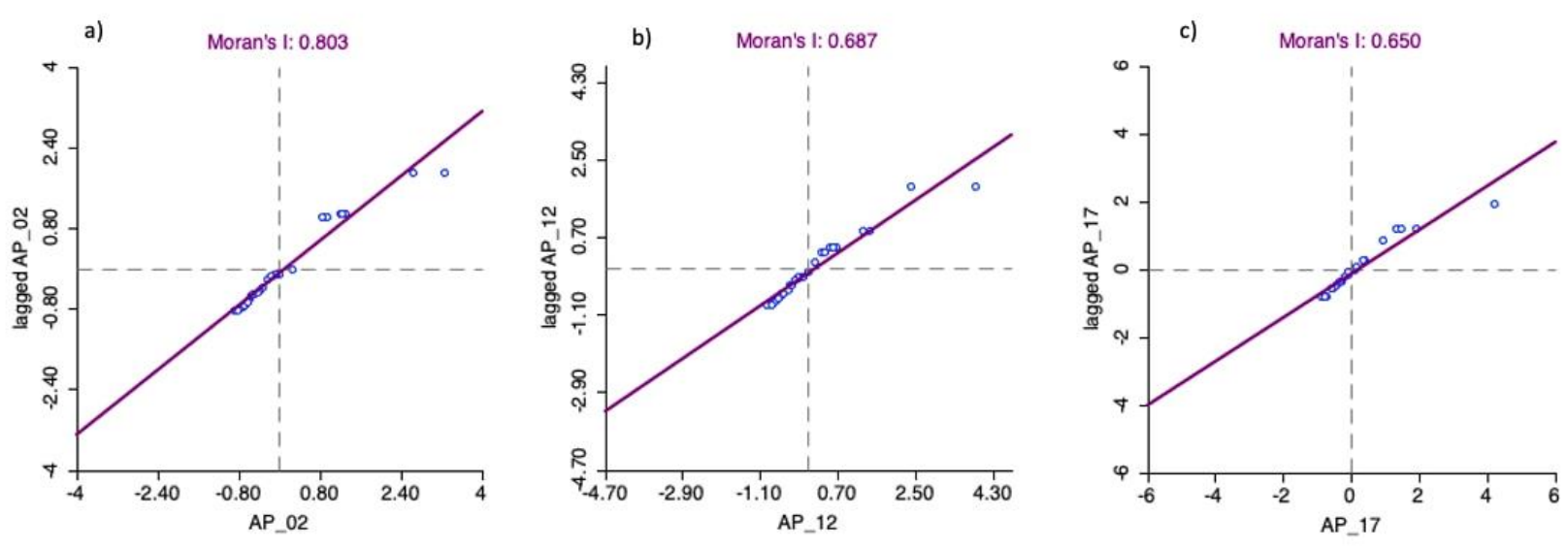

Figure 8 - Global Moran's I univariate scatter plots for motorization rate within the Greater Santiago, periods 2002 (a), 2012 (b), and 2017 (c). Source: Authors' elaboration.

The results of the Global Moran's I presented in Figure 8, shows a positive autocorrelation (greater than 0.50 ) within the municipalities of Greater Santiago for the analyzed periods. However, this measurement method does not manage to clearly identify the local changes that the identification of auto value groups has between different spatial units since Global Moran's I analyze the territory homogeneously. To identify heterogeneity between municipalities and to identify patterns of spatial autocorrelation at a local level within the AMS, the local version of Moran's I (LISA) was used, the results of which are shown in the LISA maps (see Figure 9). The municipalities with high values of number of automobiles per inhabitant are represented as High-High groups, those with low values of number of automobiles per inhabitant are considered as Low-Low, and those values of municipalities that do not manage to find a clear pattern of 
spatial autocorrelation on the indicator number of automobiles per inhabitant are considered as High-Low (closer to the High-High groups) or Low-High (closer to the Low-Low groups).
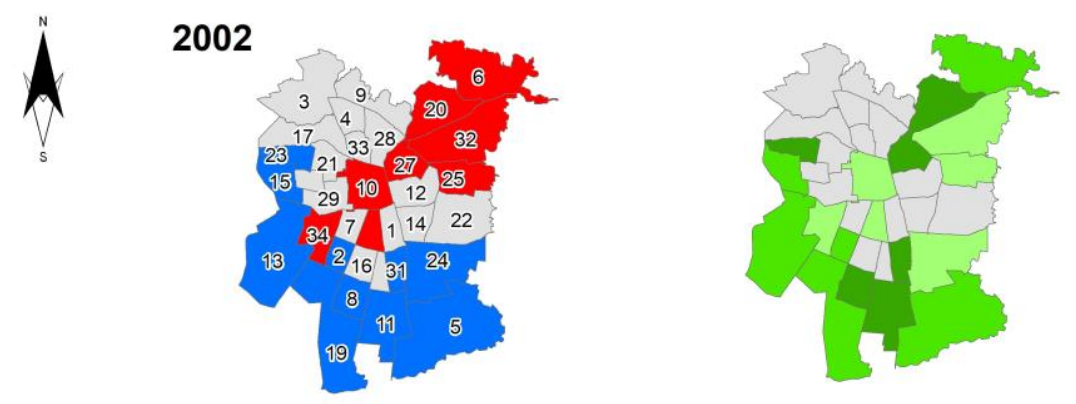

2012
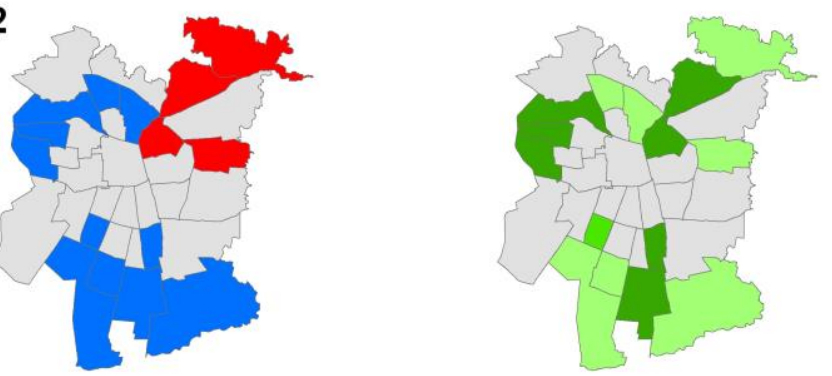

2017
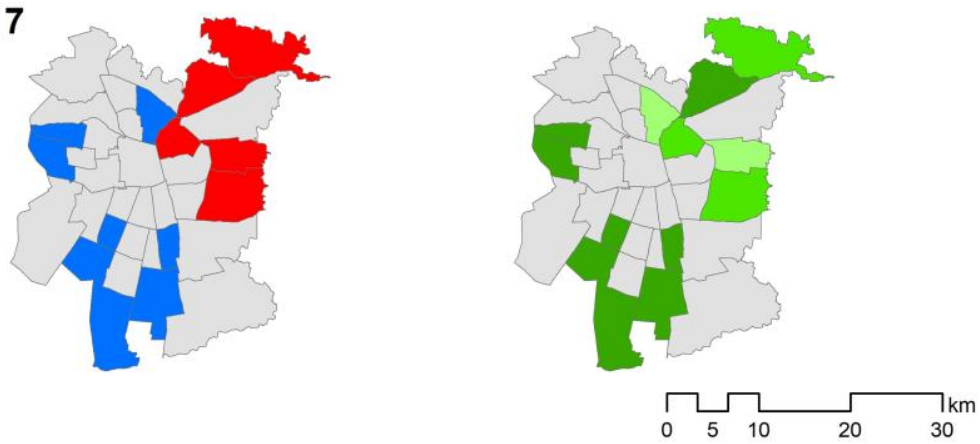

Legend

\begin{tabular}{|c|c|}
\hline LISA Cluster & LISA Significant \\
\hline Not significant & Not significant \\
\hline High-High & $p=0.05$ \\
\hline Low-Low & $p=0.01$ \\
\hline Low-High & $p=0.001$ \\
\hline
\end{tabular}
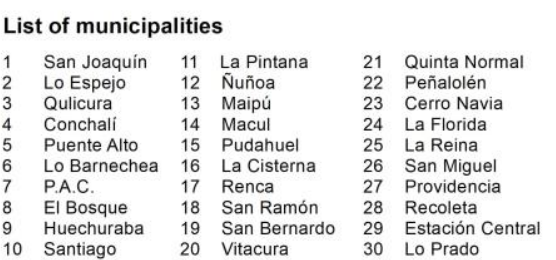

31 La Granja 32 Independencia 34 Cerrillos

Lan

$\begin{array}{lll}27 & \text { Providencia } \\ 28 & \text { Recoleta }\end{array}$

Estación Centra
Lo Prado

Figure 9 - Univariate Moran's I LISA cluster maps for motorization rate within the Greater Santiago, between 2002 and 2017. Source: Authors' elaboration.

Figure 9 allows the identification of spatial autocorrelation between municipalities in the central and eastern sectors (High-High group) and another group marked by autocorrelation of municipalities in the southern and western sectors of the AMS (Low-Low group). These groupings are mainly based on the fact that their observation values (number of automobiles per inhabitant) are very similar within the distribution of the municipalities. The relationship between the number of automobiles and inhabitants per municipality reflects a high correlation (see Figure 4). However, the analysis of cluster identification within the Greater Santiago shows that there are groups of municipalities that remain in High-High groups between 2002 and 2017, and that are located towards the western sector of the area, highlighting the municipalities of Providencia, Las Condes, Vitacura, and La Reina. Likewise, this tendency is maintained in those Low-Low groups that are located to the south of the city, highlighting the municipalities of Puente Alto, La Pintana, and San Bernardo. 


\section{Analysis of urban transport problem components}

Finally, analyzing the AMS finds its interest as a case study to observe some relations between factors related to the relationship between automobiles and inhabitants, such as poverty, quality of life, the average length of streets, and income. The analysis of this area as indicated is a good example of the situation that the country would experience on a national scale, especially considering the demographic context of the region. Thus, Figure 10 shows the four regressions with their statistical values.

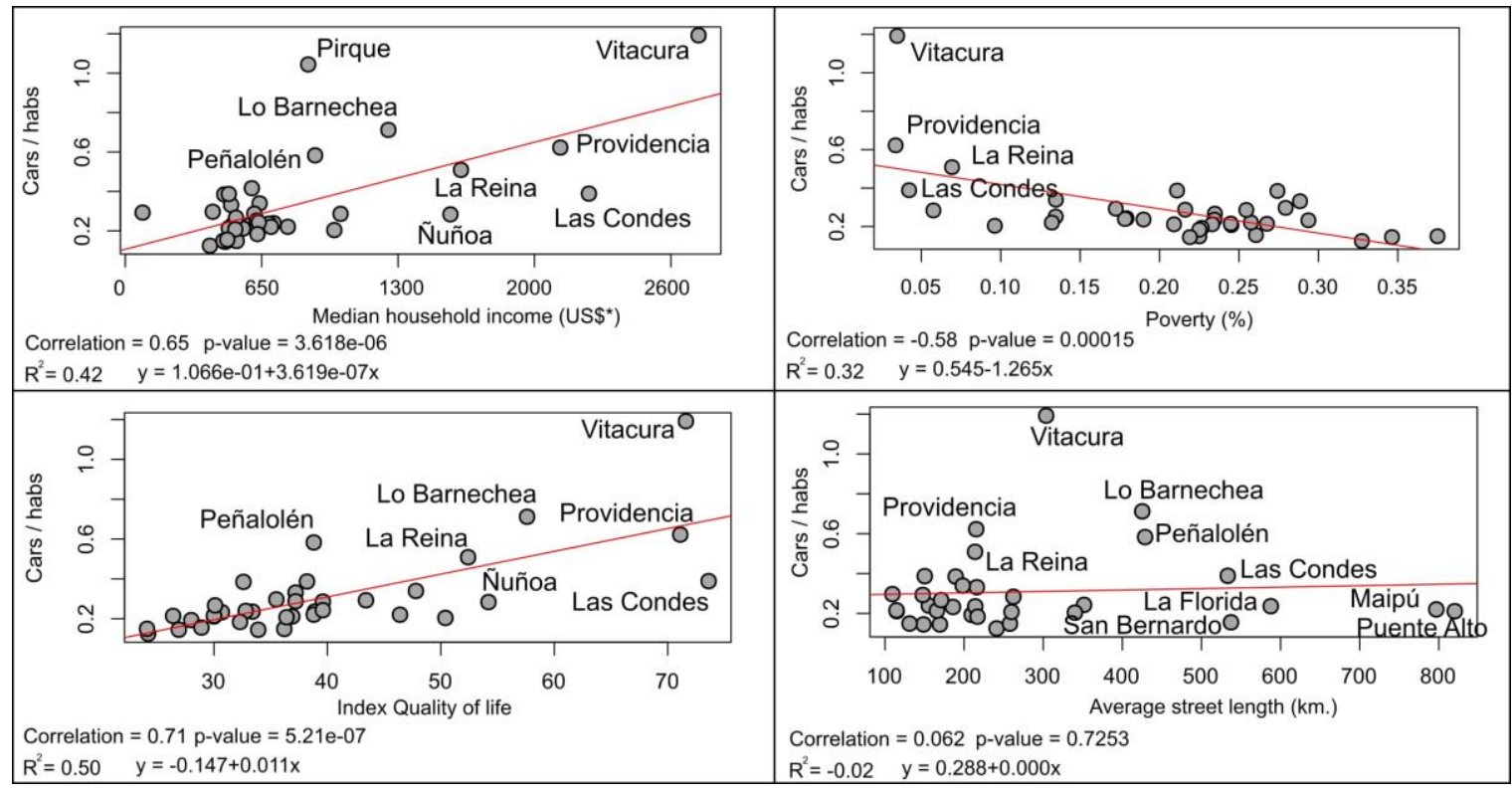

Figure 10 - Regression between the number of automobiles per inhabitant and the variables of poverty, average household income, quality of life, and the average length of streets. Source: Authors' elaboration based on CASEN, 2017; UC-CCHC, 2017; INE, 2018.

As can be seen in Figure 10, the correlation between the number of automobiles and the variables of average household income, quality of life index, and poverty are important and statistically significant. It is found that municipalities with the highest incomes and the lowest levels of poverty are those with the majority of access to automobiles. Although it is expected, considering the relationship that could be anticipated between income and poverty, the result is not necessarily evident, considering that Chile is a country with a diverse offer of automobile brands that exceed 70 in the different segments (Autofact, 2019) and with strong access to credit in this area, that encourages and enables such consumption (Pérez-Roa, 2020). This trend is similar to what occurs in countries like the United States (McAlinden et al., 2010) or the Asian continent (Muhammad et al., 2012).

\section{Discussion}

In general terms, the analysis of the automotive fleet for the different cities of Chile shows that there is an evident pressure on the environment and that it would put their sustainability in check. From the statistical point of view, the linear regression analyses reflect the generalized behavior of urban areas in Chile regarding the use of automobiles in relation to the number of inhabitants. Regarding the furthest points from the regression line, some cases are relevant to analyze. The first point, which can also be seen in the residuals figure (see Figure 5), corresponds to the municipality of Puerto Saavedra, located in the $L a$ Araucanía Region. Its geomorphological configuration, with an area of $12 \%$ of water bodies and a $75 \%$ agricultural land-use cover (Universidad Mayor de Chile, 2011), linked to the high poverty rates of 54.2\% (CASEN, 2017), and its rurality, could explain that the used means of transport can be of another kind such as animal traction, boat, or bicycle. As shown in Figure 5, the situation in Puerto Saavedra is repeated in all the analyzed periods and is also observable in other municipalities in the region. 
As for the municipalities that presented a greater number of motorized vehicles according to their size, it is wider. On the one hand, there are municipalities whose link to the tourism sector, as in the case of the municipality of El Quisco, could be explaining such dynamics. In this sense, this territory has a greater number of automobiles than inhabitants. This phenomenon may be since the municipality has large real estate projects for second homes (Zunino, Mattossian \& Hidalgo, 2012), additionally, the municipality allows receiving seasonal tourists and is close to the Metropolitan Region of Santiago.

In this sense, these urban development trends based on the use of the automobile break the paradigms of sustainable mobility (Banister, 2008). That is, Chilean cities are expected to modify their mobility patterns based on the use of automobiles generating greater pressure both in metropolitan and non-metropolitan spaces. These changes promote dynamics of change in the configurations of planned land uses. The latter should be able to mitigate the effects and impacts generated by automobile use, improving the benefits of mobility while reducing spatial friction in the city.

On the other hand, as far as the metropolitan areas are concerned, it is evident that the municipalities that compose the Greater Concepción have presented a larger dynamism than the Greater Valparaíso. This dynamic could be explained by the morphology of the city and transport policies. The first mentioned metropolitan area presents the train (named Biotren) that remains incipient, giving prominence to the automobile. Besides, its urban development has been extended by the coastal sector. On the other hand, the area of the Greater Valparaíso is also covered by a single-route train (named Metrotren) and its expansion has tended to develop inland since several coastal communities emerge somewhat 'confined' by different landforms. In the case of the Greater Santiago, it has shown an upward curve, with a slight stabilization between 2008 and 2009, observable in the other two conglomerates and where the world economic crisis is expressed. The comparison of these three areas is necessary to be made in relative terms.

Such situation is relevant especially in terms of sustainability that could be presenting the urban areas that compose the municipalities, in line with not repeating the same problems that consolidated metropolitan areas experienced, particularly with pollution, congestion, and others linked to indiscriminate use of the automobile.

For the case of the Greater Santiago, the analysis of territorial distribution confirms clustering patterns based on the relationship between the number of automobiles and inhabitants, and this is due to the high statistical significance that has a positive location of self-values or observation values for the municipalities of study, as well as for other studies analyzed for this study area (Cortés \& Iturriaga, 2019).

Another particular analysis corresponds to the municipalities that present a better quality of life, which would also be linked to those that present greater access to automobiles. Beyond the fact that this index of well-being can be explained by income or other variables, how interesting could be to deduce, at least indirectly, if the negative externalities of heavy automobile use (time, costs, etc.) would not be impacting the quality of life in the municipalities of Chile. Also, when the length of the number of streets is observed, there is no correlation with automobile ownership. This is important, considering that the population in municipalities with higher incomes, lower levels of poverty, and more automobiles are willing to travel in their vehicle beyond the comfort that it could generate. The construction of the road network becomes secondary as a variable and is an element to consider in future planning.

\section{Conclusions}

The process of globalization in Chile has played an important and active role in the movement of capital, lower tariffs in terms of buying technology including automobiles. This, linked to the greater purchasing capacity of the population and access to financing, allowing a considerable increase in the country's automotive fleet.

In this article, it was possible to confirm that the regional, non-metropolitan, and some provincial capitals have shown very rapid growth rates, above the three classic metropolitan areas of the country, which have practically tripled in 17 years, facing challenges mainly in terms of infrastructure and access. Additionally, it was proven that a variety of municipalities that express greater growth in their motor vehicle fleet are the richest areas where high-income sectors are located and have a greater amount of 
municipalities population. On the other hand, poor municipalities exhibit a slower dynamic in their automotive growth, elements that could be positive if an efficient intra and interurban transportation network existed, an aspect that is not the case in a great part of the country. Said reality affects the inhabitance of their population and has a direct relation in the sustained increase from 2002 to 2017 in the motorization rate, at a level of the main urban areas of the country.

In line with the above, the results have shown that income is a determining factor for automobile access and that in large urban agglomerations in Chile this situation becomes more evident. This being a similar characteristic to large urban areas worldwide. Likewise, making it clear that the quality of life would not be affected and the road layout would be a variable of little relevance in terms of automobile ownership. In this sense, the sustainability of the cities would face an important threat given the high consumption of automobiles per capita and, nevertheless, the inhabitants continue consuming this type of goods, since this would allow greater comfort and accessibility that possibly the public transport has not been able to grant.

The impacts on the quality of life and sustainability of cities are reflected in the sustained growth of automobile use in Chilean cities, and in particular in the Metropolitan Area of Santiago, where the population variable is the one that is most directly related. This is reflected in various studies that analyze the relationship of the hierarchy of the city system with the size of its population. The latter is in line with new researches that measures the degree of accessibility to opportunities based on the use of public transport for the Chilean case (for example, Basso et al., 2020).

In this aspect, it is relevant that studies approach the social and cultural variables of such massive use to the detriment of other types of public transport, especially when are directly related to the increase in urban populations. Thus, this study contributes to generating evidence for public decision-makers to define clear strategies for automobile use.

\section{Data availability statement}

The dataset that supports the results of this paper is available at SciELO Data and can be accessed via https://doi.org/10.48331/scielodata.PYD4C8

\section{References}

Anselin, L. (1995). Local indicators of spatial association — LISA. Geographical Analysis 27(2), 93-115.

https://doi.org/10.1111/j.1538-4632.1995.tb00338.x

Anselin, L. (2005). Exploring spatial data with GeoDa: A workbook. Urbana: Center for Spatially Integrated Social Science. Illinois: University of Illinois, Urbana-Champaign.

Autofact (2019, 5 october). Marcas de autos en Chile. Retrieved on December 7th, 2020 from

https://www.autofact.cl/blog/comprar-auto/mercado/marcas-autos-chile.

Banister, D. (2008). The sustainable mobility paradigm. Transport Policy, 15, 73-80.

https://doi.org/10.1016/j.tranpol.2007.10.005

Basso, F., Frez, J., Martínez, L., Pezoa, R., \& Varas. M. (2020). Accessibility to opportunities based on public transport gpsmonitored data: The case of Santiago, Chile. Travel Behaviour and Society, 21, 140-153. https://doi.org/10.1016/j.tbs.2020.06.004

Basurto, R. (2010). Estructura y recomposición de la industria automotriz mundial: Oportunidades y perspectivas para México. Economía UNAM, 10(30), 75-92.

Barbero, J. A., \& Galeota, C. (2019). Urban Transportation. The Wiley Blackwell Encyclopedia of Urban and Regional Studies, 1-12. https://doi.org/10.1002/9781118568446.eurs0401

Barter, P. (2001) Transport Choices for Malaysian Cities and Towns. Consumers' Association of Penang National Seminar on Changing Direction - Towards Sustainable Transport in Malaysia, 7-10 September 2001.

Camagni, R., Gibelli, M., \& Rigamonti, P. (2002). Urban mobility and urban form: the social and environmental costs of different patterns of urban expansion. Ecological Economics, 40(2), 199-216. https://doi.org/10.1016/S0921-8009(01)00254-3 
Curtis, C. (2008). Planning for sustainable accessibility: The implementation challenge. Transport Policy, 15, 104-112. https://doi.org/10.1016/j.tranpol.2007.10.003

Encuesta de Caracterización Socioeconómica Nacional CASEN (2017). Database: Encuesta de Caracterización Socioeconómica Nacional año 2017. Santiago: Ministerio de Desarrollo Social, Gobierno de Chile.

Coronado, J., \& Garmendia, M. (2008). Carreteras-planeamiento. Algunas claves de la evolución histórica de una relación imperfecta. Revista del Instituto Universitario de Urbanística de la Universidad de Valladolid, 11, 33-51.

https://doi.org/10.24197/ciudades.11.2008.33-51

Cortés, Y., \& Iturriaga, V. (2019). Market versus public provision of local goods: An analysis of amenity capitalization within the Metropolitan Region of Santiago de Chile. Cities, 89, 92-104. https://doi.org/10.1016/j.cities.2019.01.015

Cottineau, C., Hatna, E., Arcaute, E., \& Batty, M. (2017). Diverse cities or the systematic paradox of Urban Scaling Laws. Computers, Environment and Urban Systems, 63, 80-94. https://doi.org/10.1016/j.compenvurbsys.2016.04.006

Cox, T., \& Hurtubia, R. (2016). Vectores de expansión urbana y su interacción con los patrones socioeconómicos existentes en la ciudad de Santiago. Revista EURE, 42(127), 185-207. https://doi.org/10.4067/S0250-71612016000300008

Dávalos, D., Maldonado, D., \& Polit, D. J. (2016). The Hidden Potential behind the City Planned for Cars. Procedia Engineering, 145, 924-931. https://doi.org/10.1016/j.proeng.2016.04.120

Echeñique, M. (1995). Entender la ciudad. Revista EURE, 21(64), 9-23.

Elmansouri, O., Almhroog, A., and Badi, I. (2020). Urban transportation in Libya: An overview. Transportation Research Interdisciplinary Perspectives, 8, 100161. https://doi.org/10.1016/j.trip.2020.100161

Errázuriz, T. (2016). Ocio, placer y (auto)movilidad en la construcción simbólica de los "alrededores de Santiago. Revista EURE, 42(127), 279-305. https://doi.org/10.4067/S0250-71612016000300012

Errázuriz, T. (2010). El asalto de los motorizados. El transporte moderno y la crisis del tránsito público en Santiago, 1900 -192. Historia, 43(2), 357-411. https://doi.org/10.4067/S0717-71942010000200002

Figueroa, O. (2013). Four decades of changing transport policy in Santiago, Chile. Research in Transportation Economics, 40(1), 8795. https://doi.org/10.1016/j.retrec.2012.06.031

Figueroa, O. (2005). Transporte urbano y globalización. Políticas y efectos en América Latina. Revista EURE, 31(94), 41-53. https://doi.org/10.4067/S0250-71612005009400003

Gutiérrez, A., \& Delclòs, X. (2016). The uneven distribution of evictions as new evidence of urban inequality: A spatial analysis approach in two Catalan cities. Cities, 56, 101-108. https://doi.org/https://doi.org/10.1016/j.cities.2016.04.007

Hernández, D., \& Dávila, J. D. (2016). Transport, urban development and the peripheral poor in Colombia - Placing splintering urbanism in the context of transport networks. Journal of Transport Geography, 51, 180-192.

https://doi.org/10.1016/j.jtrangeo.2016.01.003

Hidalgo, D., \& Huizengra, C. (2013). Implementation of sustainable urban transport in Latin America. Research in Transportation Economics, 40(1), 66-77. https://doi.org/10.1016/j.retrec.2012.06.034

Instituto Nacional de Estadísticas de Chile - INE. (2019). Ciudades, pueblos, aldeas y caseríos 2019. Santiago de Chile: Gobierno de Chile.

Instituto Nacional de Estadísticas de Chile - INE. (2018a). Metodología para medir el Crecimiento Urbano de las Ciudades de Chile. Santiago de Chile: Comisión de Estudios Habitacionales y Urbanos, del Ministerio de Vivienda y Urbanismo, Gobierno de Chile.

Instituto Nacional de Estadísticas de Chile - INE. (2018b). Castro Maestro de Calles. Santiago de Chile: Gobierno de Chile. Instituto Nacional de Estadísticas de Chile - INE. (2017). Base censo 2017. Santiago de Chile: Gobierno de Chile, INE. Instituto Nacional de Estadísticas de Chile - INE. (2002). Base censo 2002. Santiago de Chile: Gobierno de Chile, INE. Instituto Nacional de Estadísticas de Chile - INE. (2001). Parque de Vehículos en Circulación 2001. Santiago de Chile: Gobierno de Chile, INE.

Johansson, E., Winslott, L., Koglin, T., \& Wretstrand, A. (2017) Evaluation of public transport: regional policies and planning practices in Sweden. Urban Planning and Transport Research, 5(1), 59-77. https://doi.org/10.1080/21650020.2017.1395291

Lukas, M., \& López-Morales, E. (2018). Real estate production, geographies of mobility and spatial contestation: A two-case study in Santiago de Chile. Journal of Transport Geography, 67, 92-101. https://doi.org/10.1016/j.jtrangeo.2017.09.005 
Machao da Silva, C., Heiki, L., Neto, I., \& Günther, H. (2019). Diachronic Analysis of Florianópolis Urban Morphology and the Impact on Urban Mobility Related to Brasília. European Journal of Sustainable Development, 8(5), 459-469.

https://doi.org/10.14207/ejsd.2019.v8n5p459

Mcalinden, S., Dziczek, K., Menk, D. M., \& Cregger, J. (2010). The Impact of the U.S. Economy of the Successful Automaker Bankruptcies. Michigan: Center for Automotive Research, U.S.

Moran, P. A. (1948). The interpretation of statistical maps. Journal of the Royal Statistical Society: Series B Methodological, 10(2), 243-251. https://doi.org/10.1111/j.2517-6161.1948.tb00012.x

Morales, M. (2015). Instrumentos y procesos para el desarrollo del ordenamiento territorial en Chile. Politeia, 38(55), 55-76.

Muhammad, F., Yahya, M., Hussin, M., \& Razak, A. (2012). Automobile Sales and Macroeconomic Variables: A Pooled Mean Group Analysis for Asean Countries. IOSR Journal of Business and Management, 2, 15-21.

Orellana, A., Bannen, P., Fuentes, L., Gilabert, H., \& Pape, K. (2013). Huellas del proceso de metropolización en Chile. Revista INVI, 28(77), 17-66. https://doi.org/10.4067/S0718-83582013000100002

Pérez, L., \& Salinas, E. (2007). Crecimiento urbano y globalización: Transformaciones del área Metropolitana de Concepción, Chile, 1992-2002. Revista electrónica de geografía y ciencias sociales, 11(251).

Pérez-Roa, L. (2020). Consumo, endeudamiento y economía doméstica: una historia en tres tiempos para entender el estallido social. In K. Araujo (ed.), Hilos tensados. Para leer el octubre chileno (pp. 83-105). Santiago: Editorial Usach.

Pumain, D., Bretagnolle, A., \& Degorge-Lavagne, M. (1999). La ville et la croissance urbaine dans l'espace-temps. Mappemonde, 55(3), 38-42.

Pumain, D. (1997). Pour une théorie évolutive des villes. L'Espace Geographique, 26(2), 119-134.

Ramanathan, R. (2000). Link between population and number of vehicles. Cities, 17(4), 263-269. https://doi.org/10.1016/S02642751(00)00022-6

Sagaris, L. (2018). Citizen participation for sustainable transport: Lessons for change from Santiago and Temuco, Chile. Research in Transportation Economics, 69, 402-410. https://doi.org/10.1016/j.retrec.2018.05.001

Sheller, M., \& Urry, J. (2008). The City and the Car. International Journal of Urban and Regional Research, 24(4), 737-757. https://doi.org/10.1111/1468-2427.00276

Tiznado-Aitken, I., Muñoz, J., \& Hurtubia, R. (2018). The Role of Accessibility to Public Transport and Quality of Walking Environment on Urban Equity: The Case of Santiago de Chile. Transportation Research Record, 2672(35), 129-138.

https://doi.org/10.1177/0361198118782036

Tiwari, G. (1999). Towards A Sustainable Urban Transport System: Planning for Non-Motorized Vehicles in Cities. Transport and Communications Bulletin for Asia and the Pacific, 68, 49-66.

Universidad Mayor de Chile (2011). Documento de diagnóstico. Estudio de Riesgo y Actualización PRC de Saavedra. Etapa 4: Diagnóstico. Temuco: OPPTA Observatorio Panamericano Paisaje Territorio y Arquitectura.

Ureta, S. (2009). Manejando por Santiago. Explorando el uso de automóviles por parte de habitantes de bajos ingresos desde una óptica de movilidad sustentable. Revista EURE, 35(105), 71-93. https://doi.org/10.4067/S0250-71612009000200004

Yáñez, C., \& Badia-Miró, M. (2011). El consumo de automóviles en la América Latina y el Caribe (1902-1930). El trimestre económico, 78(310), 317-342.

Zunino, H., Matossian, B., \& Hidalgo, R. (2012). Poblamiento y desarrollo de enclaves turísticos en la Norpatagonia chileno-argentina. Migración y frontera en un espacio binacional. Revista de Geografía Norte Grande, 53, 137-158. https://doi.org/10.4067/S0718-34022012000300009

Editor: Fábio Duarte

Received: Mar. 19 2021

Approved: Sep. $15^{\text {th }} 2021$ 